prospecting has been going on to determine its extent and to locate its source in the bed-rock. The ore is mostly cassiterite, but stannite also occurs. Pebbles of slate containing small tin-bearing quartz veins have been found in the gravels, while elsewhere the ore has been found disseminated through more or less altered granitic dykes.

\section{PRIZE SUBJECTS OF THE INDUSTRIAL SOCIETY OF MULHOUSE.}

THE Industrial Society of Mulhouse has issued a programme of the prizes to be awarded by the society in 1905 ; excluding the subjects which are of a purely local or technical character, the following are the principal prizes open to competition to all nationalities :-

In the section of chemistry, medals of honour will be given for experimental investigations of the alizarine reds, of the colouring matter of raw cotton, of the transformation of cotton into oxycellulose, and of cochineal carmine; for the svnthesis of the colouring matter of cochineal or of some other dye used in industry ; and for the production of fast dyes of a specified nature. Several medals will also be awarded for studies of special mordants and for the synthesis of some naturally occurring substance. A sum of 500 francs to Ioon francs is to be allotted to the best compilation of densities of mineral and organic substances in the solid state and in cold saturated solution. Many practical chemical problems in the bleaching and dyeing of cotton, wool, and silk are also suggested as subjects for competition.

In the section of mechanical arts, a prize of 500 francs and a silver medal is offered for a new method of construction of buildings suitable for cotton spinning, wool combing, or calico printing. The following subjects will receive medals :-a new non-tubular type of boiler; an indicator of the total work done in a steam engine; a new system for heating steam boilers; various machines for combing, carding, and weaving the textile fibres; a comparative study of electric and gas lighting in factories; a system of automatic lighting by conductors of the second class.

The following subjects deal with natural history and agriculture :-a catalogue of the plants in the neighbourhood of Mulhouse, Thann, Altkirch, and Guebwiller; an account of the fauna of Alsace; a mineralogical or geological description of part of Alsace; a study of the plants or insects inimical to agriculture in the same province. A medal is also offered for an investigation of the character of Alsace in prehistoric times.

In the sections of commerce and statistics the subjects are :-a consideration of the questions of insurance against risks of transport and fire; the influence of taxation on industry; and the effect of trusts and like organisations on commerce.

\section{UNIVERSITY AND EDUCATIONAL INTELLIGENCE.}

Cambridge.-Mr. J. J. Lister, F.R.S., of St. John's College, has been appointed demonstrator of comparative anatomy.

The Board of Geographical Studies has arranged for a course of instruction in geographical surveying, to be given by Mr. Hinks at the observatory.

The council of the Senate proposes an important scheme whereby the matriculation and senior local examinations of the Universities of London, Oxford, and Cambridge shall be mutually recognised. The object is to diminish the number of distinct examinations for which schoolmasters have to prepare their pupils. The proposed conditions are set forth in the University Reporter for October II.

Mr. R. R. Webb, St. John's, Mr. G. H. A. Wilson, Clare, Mr. J. M. Dodds, Peterhouse, and Mr. E. W. Barnes, Trinity, will be the examiners for the mathematical tripos, part i., in 1905 .

Sir IsAmbard OWEN has been appointed principal of the Durham College of Science in place of the late Dr. Gurney.

Dr. Arturro Marcacci, of the University of Palermo, has been appointed professor of physiology in the University of Pavia.

NO. I 824 , VOL. 70$]$
Dr. Hermann Kosser, of the Imperial Board of Health at Berlin, has been appointed to the chair of hygiene at the University of Giessen in succession to Dr. Georg Gaffky.

THE first congregation to inaugurate the University of Leeds was held on October 6, and the honorary degrees announced in our issue of September 29 (p. 547) were conferred. The Chancellor of the university, Lord Ripon, presided.

WE learn from the Athenaeum that Dr. Hans Batterman, of the Berlin Observatory, has been appointed director of the observatory at Königsberg, and professor of astronomy at the University of Königsberg, in succession to Prof. Hermann Struve, lately appointed to the vacancy at Berlin caused by the retirement of Prof. Förster.

THE Board of Education has issued its "Syllabuses and Lists of Apparatus " applicable to schools and classes other than elementary from August 1, J904, to July 31, I905. A new subject, under the title" "Elementary Science of Common Life (Chemistry)," number twenty-six, has been added to the list of branches of science in which the board holds examinations. The list of subjects in which no examinations are held, though the subjects are recognised by the Board, has been extended, and now includes many subjects introductory to more advanced work in technology.

THE anonymous gift of roool. to the University College of Bristol announced a few days ago is, it may be hoped, an indication that the work of this institution is being appreciated in Bristol and the surrounding district. In addition to the usual courses, appropriate and systematic instruction is given at the college in those branches of applied science which are most nearly connected with the arts and manufactures. We notice that the total number of individuals, excluding medical students, attending the college during the session $1903-4$ was 1084 , of whom 596 were day students.

THE new calendar of University College, London, that for the session 1904-5, gives full particulars of several interesting new developments in the work of the college. The university courses of study, especially those in economics, have been extended, and further arrangements have been made for post-graduate courses, lectures, and research-this post-graduate work is explained fully in ten pages of the calendar. The list of papers and other publications from the scientific departments of the college, since the Dean's report of last year, runs to eight full pages, and shows that the work now being accomplished in the college is of the same high order as in previous years.

IT is reported that there is apparently a deficiency of about 200ol. for the annual working expenses of the Tata Research Institute, and on account of this the scheme for the institute is at a standstill. Referring to this, Cajew. remarks :- " The question now is whether for the sake of two or three thousand pounds India should go without a Research Institute. Is the object good or not? If it was not good, why did the Government of India promise to help it? If it is good, why should there be any stinginess on their part about it? Should a great Government refuse its support and countenance to a scheme, the expenditure on which will be repaid not only to the people of India, but also to the Government itself a hundredfold?"

THE buildings of the new technical college at Danzig were opened on October 6 in the presence of the German Emperor. The college, which has been established on a modern basis, is intended to develop the industries of West Prussia and of the city of Danzig. Shipbuilding is to receive special attention. In a speech which he made, the Emperor referred to the importance of technical education for the maintenance of Germany's position among the nations, and described the special characteristic of the German technical colleges as being their "comprehensive many-sidedness." It is, he continued, for this reason that these colleges constitute a scientific "Universitas" which may be compared justly with the old universities, and explains why the endeavour has been made to place the two kinds of institutions on an equal footing by bestowing upon the technical colleges the right to confer degrees. "May the new college," the Emperor concluded, "prosper and flourish to the glory of German learning, to the blessing of these old Prussian provinces, and to the honour of the German name!" 